\title{
Kedudukan Peraturan Kepala Daerah dalam Kemitraan Antara Pemerintah Daerah dengan DPRD
}

\author{
${ }^{1}$ Supriarno, ${ }^{2}$ Saptono Hadi \\ ${ }^{1,2}$ Universitas Nahdlatul Ulama Blitar, Indonesia \\ Email: ${ }^{1}$ priarno_sh@yahoo.com, ${ }^{2}$ saptono656@gmail.com
}

\begin{tabular}{l}
\hline Tersedia Online di \\
\hline http://www.jurnal.unublitar.ac.id/ \\
index.php/briliant \\
\hline Sejarah Artikel \\
\hline Diterima pada 09 Agustus 2019 \\
Disetujui pada 28 Agustus 2019 \\
Dipublikasikan pada 31 Agustus \\
2019 Hal. 323-330 \\
\hline
\end{tabular}

Kata Kunci:

Kedudukan, mitra, perkada

\section{DOI:}

http://dx.doi.org/10.28926/briliant .$v 3 \mathrm{i} 4.346$

\begin{abstract}
Abstrak: Maksud dari Penelitian ini merupakan sebuah bentuk untuk menganalisa, menemukan dan mengkaji kedudukan Peraturan Kepala Daerah dalam kemitraan antara Pemerintah Daerah dengan DPRD. DPRD dalam menjalankan fungsinya merumuskan kebijakan daerah baik secara langsung maupun melalui perwakilan. Salah satunya dalam memberikan pertimbangan terhadap Peraturan Kepala Daerah (Perkada). Hal ini dapat mendorong karakter produk hukum daerah khususnya Perkada oleh pemerintah daerah menjadi lebih responsif dan menjawab kebutuhan masyarakat dalam rangka untuk mewujudkan kebijakan daerah yang partisipasif. Tidaklah berlebihan jika seyogyanya bahwa substansi Perkada dapat di berikan pertimbangan oleh DPRD sebagaimana hubungan kemitraan yang sejajar antar kedua lembaga daerah tersebut demi mewujudkan sinergi kemitraan antara pemerintah daerah dan DPRD. Kajian dalam
\end{abstract} menganalisis data yang di pakai dalam penelilian ini ialah teknik kualitatif yang bersifat deskriptif. Hasil penelitian DPRD sebagai mitra pemerintahan daerah selama ini tidak ada dasar hukum untuk ikut terlibat di dalam proses pembentukan Perkada, sedangkan dari Pemerintah daerah proses pembentukan Perkada merupakan kewenagan dari eksekutif. Sebagai unsur dalam menjalankan Pemerintahan daerah, Pemerintah Daerah dalam perumusan Perkada secara etika hanya pemberitahuaan kepada DPRD diluar agenda resmi pemerintahan.

\section{PENDAHULUAN}

Ketetapan pada Pasal 18 ayat (2) UUDRI tahun 1945 dijelaskan "Pemerintahan daerah provinsi, daerah kabupaten/kota mengatur dan mengurus sendiri urusan pemerintahan menurut asas otonomi dan tugas pembantuan". Selain itu untuk mengurus sendiri urusan pemerintahan didalam Pasal 18 ayat (6) UUDNRI 1945 mengamanatkan "Pemerintahan daerah berhak menetapkan peraturan daerah dan peraturan-peraturan lain untuk melaksanakan otonomi dan tugas pembantuan". Artinya bahwa pemerintahdaerah dapat mengelola potensi daerah dan tidak terkecuali menghasilkan suatu produk hukum yang akan diberlakukan didaerah sebagai salah satu landasan hukum untuk meyelenggarakan pemerintahan daerah.

Pelaksanaan otonomi daerah merupakan memiliki keleluasaan pemerintah daerah (discretionary power) untuk menyelenggarakan pemerintah sendiri atas dasar prakarsa, kreativitas serta peran aktif masyarakat dalam upaya 
pengembangan dalam memajukan daerahnya (J. Kaloh., 2002). Untuk itu dalam menjalankan roda pemrintahan, pemerintah daerah bersama dengan DPRD memegang peran penting mejalankan prinsip otonomidaearah bersama dengan rakyat. Produk hukum daerah merupakan bentuk-bentuk peraturan hukum yang dapat digunakan dalam penyelenggaraan urusan pemerintah daerah. Apalagi produk hukum daerah yang mempunyai bentuk peraturan (regeling) yang tentunya bersifat atau berlaku secara umum (bersifat publik), dimana peraturan terdiridari (verordening) atau peraturan daerah, PKD (peratutan kepala daerah), Peraturan Kebijakan (beleidsregel, psudowetgeving) Pemerintah Daerah, Keputusan (beschikking) Pemerintah Daerah, dan peraturan bersama (gemeenschappelijk regeling) antar Pemerintah Daerah (Iza Rumesten., 2010).

Pasal 1 angka 17 Permendagri, Nomor 120 Tahun 2018 tentang perubahan atas Peraturan Peraturan Menteri Dalam Negeri Nomor 80 Tahun 2015 tentang Pembentukan Produk Hukum Daerah, Produk hukum daerah yaitu: Produk hukum Daerah dalah produk hukum berbentuk peraturan meliputi Perda atau nama lainnya, Perkada, Peraturan DPRD dan berbentuk keputusan meliputi Keputusan Kepala Daerah, Keputusan DPRD, Keputusan Pimpinan DPRD dan Keputusan Badan Kehormatan DPRD.

Peraturan Daerah juga dapat mendelegasikan dibentuknya Peraturan Kepala Daerah (Perkada) untuk melaksanakan Perda. Dalam perihal ini diterangkan dalam UUD 23 Tahun 2014 tentang peraturan Pemerintahan Daerah, Pasal 246 ayat (1) yang meyebutkan : sebagai pelaksaaan dalam melakukan Perda atau atas wewenang dalamperaturan perundang-undangan kepala Daerah menenentukan Perkada. Pada dasarnya keberadaan Perkada merupakan delegasi dari Peraturan Daerah adalah dalam rangka menjalankan Peraturan Daerah, karena dalam Peraturan Daerah secara tegas memerintahkan untuk membuat peraturan pelaksana Peraturan Daerah dalam bentuk Perkada.

Ikatan pekerjaan DPRD dengan Kepala Daerah berdasarkan jalinan kerja sama sejalan. Bahwa keduanya dalam sebuah ikatan kerja memiliki kedudukan yang sama dan sejajar, berarti keduanya memiliki hubungan yang saling mendukung. DPRD sebagai lembaga legislatif di daerah dalam menjalankan fungsinya sebagai representasi suara rakyat seyogyanya dapat memberikan pertimbangan terhadap peraturan yang bersifat umum dan mengikat kepada masyarakat tak terkecuali Peraturan Kepala Daerah (Perkada). Hal ini dapat mendorong karakter produk hukum daerah khususnya Perkada oleh pemerintah daerah menjadi lebih responsif dan menjawab kebutuhan masyarakat dalam rangka untuk mewujudkan kebijakan daerah yang partisipasif.

Ditengah arus kewenagan pemerintah daerah dalam membuat regulasi daerah muncul problematika bahwasanya banyak Perda dan Perkada yang dibatalkan oleh Kementerian Dalam Negeri (Kemendagri). Berikut data produk hukum dibatalkan/direvisi oleh Kementerian dalam negeri mulai tahun 2002 hingga dengan tahun 2016 peraturan kepala daerah dicabut/direvisi sebanyak 3143 (Sumber Bagian Pengkajian Evaluasi Produk Hukum Daerah., 2016). Alasan yang paling banyak dalam pembatalan Perda) maupun Perkada adalah bersesuaian pada undang-undag ada diatasnya serta tidak sejalan dengan, kepentinganumum. Disisi lain dalam pengambilan kebijakan pemerintah daerah sekiranya perlu melibatkan wakil-wakil rakyat sebagai mitranya dalam sistem pemerintahan 
daerah untuk sebesar-besarnya terjaminya kepentingan umum yang tidak merugikan salah satu pihak.

Berdasarkan uraian diatas muncul dua permasalahan yaitu: (1) bagaimana hubungan kemitraan pemerintah daerah dengan DPRD dalam ,pembentukan PKD (peraturan daerah_), (2) bagaimana kedudukan peraturan kepala daerah dalam renzim peraturan perundang-undangan.

Dengan melihat problematika diatas maka diperlukan sebuah mekanisme yang dapat menjadi solusi atas permasalahan dalam pembentukan suatu Perkada sebagaimana pendelegasian atau peraturan pelasana dari Perda yang berorientasi pada kebutuhan masyarakat, sehingga sebuah Perkada sejalan melalui peraturansesuai dengan kebutuhan masyarakat.

\section{METODE}

Jenis Penelitian ialah penelitian hukum campuran antara Penelitian Hukum_Normatif serta Penelitianhukum Empiris dimana pokok penlitian ini tentang Kedudukan Peraturan Kepala Daerah dalam Kemitraan antara Pemerintah Daerah dengan DPRD, Lokasi Penelitian di Pemerintah Kabupaten Blitar serta DPRD Kabupaten Blitar dimana pelaksanaan pembentukan peraturan kepala daerah dilaksanakan. Pendekatan_penelitian menggunakan pendekatan _konseptual (conceptualapproach) serta, pendekatan per-Undang-Undangan (Statute Approach). Jenis dan Sumber data: (a) Data_primer, yaitu data yang didapat secara langsung oleh penulis dari pembicara atau penjawab di lokasi penelitian. Data primer yang digunakan dalam penelitian ini adalah bagaimana pelaksanaan pembentukan Peraturan Kepala Daerah oleh Pemerintah Kabupaten Blitar dan bagaimana pelaksanaan peran oleh DPRD Kabupaten Blitar terkait pembentukan peraturan kepala daerah, (b) Data_sekunder, ialah data yang berasal dari referensi yang terdapat dari buku, pembentukan peraturan perundangundangan dan terkait pembentukan Perkda serta data-data dari pihak Pemerintah Daerah dan DPRD Kabupaten Blitar. Teknik Pengumpulan Data diperoleh melalui : (1) melakukan penelitian langsung di lingkungan DPRD Kabupaten Blitar dan Pemerintah Kabupaten Blitar, (2) Wawancara langsung dengan para narasumber diantaraya anggota DPRD Kabupaten Blitar dan bagian hukum Pemerintah Kabupaten Blitar. Wawancara dilakukan dengan mengunakan sistem terbuka sehingga pertanyaan dapat langsung ditanyakan secara bebas sebagaimana untuk mendapatkan data yang signifikan dari penelitian. (3) melaksanakan pencarian bahan pustaka,informasi, serta bahan yang dapat dipakai sebagai penunjang penelitian. Teknik Pengolahan Data dilakukan dengan teknik analisa kualitatif yang bersifat deskriptif, yaitu dengan menonjolkan kualitas dari data yang diperoleh, dengan bantuan unsur-unsur yang ada dalam kajian atau studi pustaka dan lapangan. Analisa kualitatif bisa juga digunakan untuk mendapatkan data yang mendalam, suatu data yang mengandung makna serta dapat memberikan gambaran pada peraturan per-undang-undangan hingga mencapai suatu pendapat publik. Sedangkan dalam penggunaannya data_kuantitatif sebagai alat dalam mempertajam analisa kualitatif.

\section{PEMBAHASAN}

\section{Hubungan Kemitraan Pemerintah Daerah dengan DPRD dalam Pembentukan Peraturan Kepala Daerah}


Undang-Undang No. 23 Tahun 2014 tentang PD (pemerintahan daerah) menyatakan bahwa "Pemerintahan Daerah adalah penyelenggaraan urusan pemerintahan oleh pemerintah daerah dan dewan perwakilan rakyat daerah menurut asas otonomi dan tugas pembantuan dengan prinsip otonomi seluasluasnya dalam sistem dan prinsip Negara Kesatuan Republik Indonesia sebagaimana dimaksud dalam Undang-Undang Dasar Negara Republik Indonesia Tahun 1945. Penyelenggaraan pemerintahan daerah berbeda dengan penyelenggaraan pemerintahan di pusat yang terdiri atas lembaga eksekutif, legislatif, dan yudikatif, penyelenggaraan pemerintahan daerah dilaksanakan oleh DPRD dan kepala daerah. DPRD dan kepala daerah berkedudukan sebagai unsur penyelenggara pemerintahan daerah yang diberi mandat rakyat untuk melaksanakan urusan pemerintahan yang diserahkan kepada daerah. Dengan demikian maka DPRD dan kepala daerah berkedudukan sebagai mitra sejajar yang mempunyai fungsi yang berbeda. DPRD mempunyai fungsi pembentukan Perda, anggaran dan pengawasan, sedangkan kepala daerah melaksanakan fungsi pelaksanaan atas Perda dan kebijakan Daerah. Dalam mengatur dan mengurus Urusan Pemerintahan yang menjadi kewenangan Daerah tersebut, DPRD dan kepala daerah dibantu oleh Perangkat Daerah".

Hubungan Pemerintah Daerah dan DPRD dengan jelas diatur dalam Pasal 207 Undang-Undang Nomor 23 Tahun 2014 tentang pemerintah daerah menjelaskan "Hubungan kerja antara DPRD dan kepala daerah didasarkan atas kemitraan yang sejajar". Ketentuan itu bermaksud ke-duanya baik Pemerintahan Daerah serta DPRD, dalam hubungan kerja kesetaraan yang sama. DPRD sebagai unsur penyelenggara pemerintahan daerah mempunyai kedudukan yang sama dalam membangun dan mengusahakan dukungan dalam penetapan kebijakan pemerintahan daerah, dimana dapat menampung dan menyalurkan aspirasi masyarakat sehingga kebijkan dimaksud dapat diterima oleh masyarakat.

Reposisi kelembagaan pemerintahan daerah antara pemerintah daerah dan DPRD menjadi pola hubungan yang sejajar dilaksanakan dengan memperhatikan hubungan kemitraaan di mana satu sama lain saling bekerja sama dalam mewujudkan pemerintahan daerah yang berpihak pada kepentingan masyarakat, penyediaan kebutuhan dan pelayanan publik, dalam rangka mewujudkan kesejahteraan dan kemakmuran masyarakat lokal (Hari Sabarno., 2008). Dalam perumusan peraturan kepala daerah yang bersifat mengatur secara umum seyogyanya antara pemerintah daerah dan DPRD dapat menjadikan media konsultasi sebagai sarana untuk lebih terjaminya pembangunan daerah untuk sebesar-besarnya demi kesejahteraan masyarakat. Hal yang menarik bahwa kesadaran serta kepercayaan hukum sebagai dasar yang baik bagi rakyat serta masayarakat (Satjipto Raharjo., 2009).

H. D. Stoud dalam teori wewenangnya menyatakan wewenang dapat diartikan sebagai kesemua aturan yang berhubungan dengan pendapatan serta pemakaian wewenang pemerintah yang dilalakukan subjek hukum publik pada hukum publik (Irfan Fachruddin., 2004). Dalam hal ini sejatinya pembentukan Perkada wewenang dari pemerintah daerah, namun dalam pelaksanaanya seyogyanya wewenang tersebut terlebih dahulu dimulai dari etika komunikasi yang baik sebagai bentuk konkrit daripada hubungan kemitraan antara pemerintah daerah dengan DPRD sebagai organ dalam penyelenggara pemerintahan daerah 
Pemahaman mengenai hubungan kemitraan ini mutlak harus menjadi landasan setiap sikap tindak kedua lembaga tersebut. Hubungan kemitraan yang terjalin antara pemerintah daerah dan DPRD diimplementasikan dengan perilaku koreksi ke arah solusi serta demi membagun hubungan yang harmonis antar keduanya. DPRD bukanlah suatu lembaga yang berhadap-hadapan sebagai lawan dari kepala daerah. Akan tetapi kedua lembaga tersebut harus senantiasa dapat saling membantu untuk melaksanakan pemerintahan_daerah yang dapatberpihak pada rakyat.

Berdasarkan hasil penelitian hubungan antara DPRD dan Pemerintah Daerah merupakan hubungan yang saling koreksi dalam menajalan roda Pemerintahan Daerah. DPRD sebagai lembaga legislatif berkeja sebagaimana tugas pokok fungsinya yang diatur dalam peraturan perundang-undangan sedangkan pemerintah daerah berkeja sebagaimana fungsi pemerintahan seperti pelayanan kepada masyarakat. Artinya DPRD memerankan peran penting dalam mengontrol jalannya pemerintahan sehingga berjalan sesuai dengan tujuan yang sudah tetapkan.

Montesquieu pada hakikatnya tidak mengajukan usul bentuk pemisahan yang bersifat kaku atau mutlak, dan ia menjabarkan sejumlah contoh dimana kekuasaan suatu eksekutif, legislatif dan yudikatif saling tumpang tindih satu sama lain, yang pada dasarnya kekuasaan raja untuk memveto ialah termasuk dalam cabang legislatif, dan hak parlemen dalam menyelidiki bagaimana hukum dijalankan serta hak untuk menuntut pertanggungjawaban para menteri raja menyebabkan tumpang tindih dengan kekuasaan eksekutif (M. Khoiril Anam., 2007). Demokrasi perwujudanya yakni terdapat pemerintahan yang bersendiakan perwakilan_rakyat, kekuasaan dan kewenaganya berasal dari rakyat dan dijalankan melalui wakil serta, bertanggung jawaban penuh kepada rakyat. Artinya setiap kebijakan yang dilakukan atau yang diperbuat oleh pemerintah harus berdasarkan kesepakatan dengan wakil rakyat, yang mana wakil rakyat mendapat kontrol yang ketat dari yang diwakilinya (A.Mukthie Fadjar., 2005)

\section{Kedudukan Peraturan Kepala Daerah dalam Renzim Peraturan Perundang- Undangan}

Pemecahan masalah-masalah pembangunan di daerah di dalam era otonomi daerah menempatkan produk kebijakan pemerintah daerah dan DPRD menjadi sangat strategis. Pembentukan ketetapan strategis sejatinya bertujuan untuk pemecahan masalah-masalah di daerah. Masalah-masalah yang timbul di daerah dapat dilihat dari hasiltemuan-temuan daripada aktualisasi fungsi oleh lembaga Pemerintah Daerah dan DPRD. Dalam hal ini terkait proses perumusan produk hukum daerah sebagaimana sebagai bentuk eksekutor OTD (otonomi Daerah) serta bebanpendamping dan mewadahi keadaa eklusif daerah danatau pemaparan lebih lanjut peraturan per-undang-undangan yang lebih tinggi.

"Peraturan Dewan Perwakilan Rakyat Daerah Provinsi/Kabupaten/Kota, Peraturan Gubernur/Bupati/Walikota, Peraturan Kepala Desa atau yang setingkat".

Ketentuan dasar yang mana telah diamanatkan oleh konstitusi, maka produk hukum daerah yang dibentuk oleh pemerintahan daerah untuk melaksanakan otonomi dan tugas pembantuan ialah Perda dan peraturan-peraturan lain. Lebih lanjut pada Pasal 7 ayat (1) Undang-Undang Nomor 12 Tahun 2011 tentang 
Pembentukan Peraturan Perundang-undangan kemudian menuliskan jenis dan hierarki peraturan perundang-undangan di Indonesia terdiri atas: (a) UndangUndang Dasar Negara Republik Indonesia Tahun 1945; (b) Ketetapan Majelis Permusyawaratan Rakyat; (c) Undang-Undang/Peraturan Pemerintah Pengganti Undang-Undang; (d) Peraturan Pemerintah; (e) Peraturan Presiden; (f) Peraturan Daerah Provinsi; dan (g) Peraturan Daerah Kabupaten/Kota.

Norma mengenai produk hukum daerah ada pada Peraturan Menteri Dalam Negeri (Permendagri) Nomor 80 Tahun 2015 tentang Pembentukan Produk Hukum Daerah sebagaimana telah diubah terakhir dalam Peraturan Menteri Dalam Negeri (Permendagri) Nomor 120 Tahun 2018, bahwa Produk hukum Daerah dalah produk hukum berbentuk peraturan meliputi Perda atau nama lainnya, Perkada, Peraturan DPRD dan berbentuk keputusan meliputi Keputusan Kepala Daerah, Keputusan DPRD, Keputusan Pimpinan DPRD dan Keputusan Badan Kehormatan DPRD.

Peraturan Kepala Daerah yang berlaku keluar atau bersifat mengatur secara umum dan mengikat (regeling), A. Hamid Attamimi mengemukakan peraturan perundang-undangan yang berlaku keluar ditunjukakan kepada masyarakat umum, karena masyarakat yang terkena aturan kebijakan tersebut tidak dapat berbuat kain kecuali mengikutinya. Sebagai perbandingan adapun Peraturan Kepala Daerah yang berlaku kedalam yang berbentuk kebijakan (bleidsregel) tidak sama sekali ditunjukaan kepada masyarakat umum, tetapi mengandung relevansi hukum. Menurut Van Wijk Ada dua bentuk umum dari Peraturan kebijakan, pertama peraturan kebijakan yang dibuat dan berlaku bagi pembuat peraturan kebijakan itu sendiri, kedua kebijakan yang dibuat dan berlaku bagi badan atau pejabat administrasi yang menjadi bawahan pembuat peraturan kebijakan (Ridwan HR., 2014).

Dalam tataran pembentukan peraturan perundang-undangan dikenal teori jenjang hukum (Stufentheorie) yang dikemukakan oleh Hans Kelsen. Dalam teorinya tersebut Hans Kelsen berpendapat bahwa norma-norma hukum itu berjenjang-jenjang dan berlapis-lapis dalam suatu hierarki tata susunan, dimana suatu norma yang lebih rendah berlaku, bersumber, dan berdasar pada norma yang lebih tinggi berlaku, bersumber dan berdasar pada norma yang lebih tinggi lagi, demikian seterusnya sampai pada suatu norma yang tidak dapat ditelusuri lebih lanjut dan bersifat hipotesis dan fiktif, yaitu Norma Dasar (Grundnorm). Hans Nawiasky mengembangkan teori yang dikedepankan Kelsen dalam bukunya berjudul Algemeine Rechtlehre berpendapat bahwa selain norma itu berlapis-lapis dan berjenjang-jenjang, norma hukum dari suatu negara itu juga berkelompokkelompok. Nawiasky mengelompokkan norma-norma hukum dalam suatu negara itu menjadi empat kelompok besar yang terdiri dari : (1) kelompok I, Staatfundamentalnorm (norma fundamental negara); (2) kelompok II, Staatgrundgesetz (aturan dasar/pokok negara); (3) kelompok III, Formell Gesetz. (undang-undang formal); dan (4) kelompok IV, Verordnung \& Autonome Satzung (aturan pelaksana \&aturan ortonom) (Marsillam Simanjuntak., 1997).

Dalam tataran norma tingkatan yang lebih tinggi seperti sistem anak_tangga. Dimana Perkada haruslah sesuai dengan atau tidak boleh bertentangan dengan norma diatsnya. Selanjutnya Peraturan Kepala Daerah (Perkada) bisa dikatakan produk_regulatif maupun executive_acts yang sama dengan peratn pmrintah ataupun peraturn presiden di tingkat pusat. Produk regulatif adalah produk 
pengaturan (regulasi) oleh lembaga eksekutif yang menjalankan peraturan yang ditetapkan oleh lembaga legislatif dengan mendapatkan delegasi kewenangan untuk mengatur lebih lanjut materi muatan produk legislatif yang dimaksud itu kedalam peraturan pelaksanaan yang lebih rendah tingkatnya. (Junimart Girsang., 2017).

Berdasarkan hasil penelitian, selama ini Peraturan Bupati (Perkada) dibuat atas kuasa dari Peraturan Daerah (Perda) atau dari peraturan perundang-undangan diatasnya. Artinya suatu pembentukan Perkada haruslah berdasarkan Perda atau peraturah perundang-undangan diatasnya. Jadi materi muatan atau substansi dari Perkada tidaklah bertentangan dengan Perda karena sebagai peraturan pelaksana dari Perda, Perkada dibuat dan disusun berdasarkan perintah dari Perda.

Secara teoritis dalamistilah per-undang-undangan memiliki dua penafsiran yaitu yang ke-1"perundang-undangan merupakan proses pembentukan atau proses membentuk peraturan-peraturan negara baik ditingkat Pusat maupun di tingkat daerah", ke-2 "per-undang-undangan ialah segala bentukperaturan negara yang merupakan_hasil_pembentukan_peraturan-peraturan_baik_ditingkat_Pusat maupun_ditingkat_daerah, (Maria Farida Indrati Soeprapto., 1998). Peraturan Perundang-Undangan merupakan putusan tertulis yang dibuat, ditetapkan sekaligus dikeluarkan oleh lembaga atau pejabat yang mempunyai (menjalankan) fungsi legislatif sesuai dengan tata cara yang berlaku (Bagir Manan dan Kuntana Magnar., 1987).

Perkada sebagai peraturan pelaksana Perda dan kuasa dari pada peraturan_per-undang-undangan. Berdasarkan hasil penelitian, menunjukkan bahwa substansi dari Perkada tidak ada yang bertentangan dengan Peraturan Daerah. Namun apablia suatu Perkada itu tidak sesuai dengan perkembangan kehidupan masyarakat maka Perkada tersbut bisa direvisi sesuai dengan kondisi masyarakat. Mekanismenya yaitu DPRD sebagai lembaga perwakilan rakyat dapat memintai keterangan dari eksekutif selaku pembentuk Perkada untuk merevisi atau mengganti apabila dirasa kurang memenuhi kebutuhan masayarakat. Dengan begitu suatu peraturan yang ada di daerah harusnya mampu menjadi jawaban dari kebutuhan masyarakat.

Selain itu karakternya patutbersifat_progresif, berarti selalu mafhum dalam keadaan riil dimasyarakat.

\section{KESIMPULAN}

Dari pembahsaan ini dapat diketahui kesimpulannya : (1) Hubungan kemitraan terjalin antara pemerintah_daerah dan DPRD dalam pembentukan Perkada yaitu diimplementasikan dengan perilaku koreksi ke arah solusi dan sebagai partner dalam membangun untuk kepentingan bersama serta melakukan kegiatan tersebut sebagai wujud pemerintah daerah memihak rakyat., (2) PKD adalah bagaian renzim Peraturan_per-undang-undangan yang pembentukannya serta materi substansinya berdasarkan atas kuasa atau Peraturan_Daerah diatasnya dalam rangka pelaksanaan roda pemerintahan daerah.

\section{SARAN}

Diharapkan dalam proses pembentukan Perkada sebagai peraturan pelaksana atas Perda maupun atas kuasa peraturan perundang-undangan diatasnya, maka Pemerintah Daerah seyognya mengkomunikasikan terlebih dahulu kepada DPRD 
baik melalui surat resmi atau melalui komunikasi verbal baik resmi ataupun tidak. Dengan dimikian komunikasi tersebut merupakan bentuk konkrit dari kemitraan antara Pemerintah Daerah dan DPRD serta diharapkan suatu Perkada dapat berkarakter responsif.

\section{DAFTAR RUJUKAN}

A. Mukthie Fadjar. (2005). Tipe Negara Hukum. Malang: Bayumedia Publishing Bagir Manan dan Kuntana Magnar. 1987. Peranan Peraturan PerundangUndangan dalam Pembinaan Hukum Nasional. Bandung: Armiko

Hari Sabarno. (2008). Untaian Pemikiran Otonomi Daerah Memandu Otonomi Daerah Menjaga Kesatuan Bangsa. Jakarta: Sinar Grafika

Iza Rumesten, (2010). Identifikasi Model Ideal Partisipasi Masyarakat dalam Pembentukan Peraturan Daerah dalam Kerangka Good Governance, Malang: Tunggal Mandiri Publishing

Junimart Girsang. (2017). Fungsi Pembentukan Peraturan Daerah Oleh Dewan Perwakilan Rakyat Daerah, Journal of Law and Policy Transformation, FH Universitas Internasional Batam (Volume 2 Nomor 1, June 2017).

Maria Farida Indrati. (1998). Ilmu Perundang-Undangan. Yogyakarta: Kanisius Marsillam Simanjuntak. (1997). Pandangan Negara Integralistik. Jakarta: Garfiti Montesquieu. (2007). The Spirit of Laws, Dasar-Dasar Ilmu Hukum dan Ilmu Politik, diterjemahkan oleh M. Khoiril Anam. Bandung: Nusamedia

Ridwan HR. (2014). Hukum Administrasi Negara Edisi Revisi. Jakarta: Rajawali Press

Satjipto Rahardjo. (2000). Ilmu Hukum. Bandung: Citra Aditya Bakti

Satjipto Raharjo. (2009). Lapisan-Lapisan dalam Studi Hukum. Malang: Bayumedia Publishing

Stout HD. (2004). de Betekenissen Van De Wet, dalam Irfan Fachruddin, Pengawasan Peradilan Administrasi terhadap Tindakan Pemerintah, (Bandung: Alumni, 2004)

Sumber Bagian Pengkajian Evaluasi Produk Hukum Daerah, Biro Hukum Kementerian Dalam Negeri, Data setelah diolah, Bulan Desember 2016.

Undang-Undang Dasar Negara Republik Indonesia Tahun 1945.

Undang-Undang Nomor 23 Tahun 2014 tentang Pemerintah Daerah (Lembaran Negara Republik Indonesia Tahun 2014 Nomor 244, Tambahan Lembaran Negara Nomor 5587)

Undang-Undang Nomor 17 Tahun 2014 tentang Majelis Permusyawaratan Rakyat, Dewan Perwakilan Rakyat, Dewan Perwakilan Daerah, Dewan Perwakilan Rakyat Daerah (Lembaran Negara Republik Indonesia Tahun 2014 Nomor 182, Tambahan Lembaran Negara Nomor 5568)

Undang-Undang Nomor 11 Tahun 2012 tentang Pembentukan Peraturan Perundang-undagan (Lembaran Negara Republik Indonesia Tahun 2011 Nomor 82, Tambahan Lembaran Negara Nomor 5234)

Peraturan Menteri Dalam Negeri Republik Indonesia Nomor 80 Tahun 2015 tentang Pembentukan Produk Hukum Daerah(Berita Negara Republik Indonesia Tahun 2015 Nomor 2036) sebagaimana telah diubah dalam Peraturan Menteri Dalam Negeri Republik Indonesia Nomor 120 Tahun 2015 tentang Pembentukan Produk Hukum Daerah (Berita Negara Republik Indonesia Tahun 2018 Nomor 157) 